\title{
Articles
}

\section{Ammonium Ion Binding Property of Naphtho-Crown Ethers Containing Thiazole as Sub-Cyclic Unit}

\author{
Hong-Seok Kim, ${ }^{*}$ Kyung Soon Do, Ki Soo Kim, Jun Ho Shim, ${ }^{\dagger}$ Geun Sig Cha, ${ }^{\dagger}$ and Hakhyun Nam ${ }^{+, *}$ \\ Department of Applied Chemisny, Kymgpook National University, Daegu 702-701, Korea \\ "Chemical Sensor Research Group, Deparment of Chemistry, Kuangwoon University, Seonl 139-701, Korea \\ Received April 20,2004
}

\begin{abstract}
A short and efficient synthesis, solvent extraction and potentiometric measurements of new thiazole-containing naphtho-crown ethers are reported. The naphthalene moicty enhances the ammonium ion selectivity over potassium ion. The selectivity of $\mathrm{NH}_{4}{ }^{+} / \mathrm{K}^{+}$follows the trend $\mathbf{3} \approx 2>1$, indicating that the differenees in conformational changes of 2 and 3 in forming ammonium complexes affect little on the resulting ammonium/ potassium extraction selectivity ratio. The ammonium ion-selective electrodes were prepared with $n$ octylphenyl ether plasticized poly(vinyl chloride) membrancs containing 1-4; the effect of one naphthalene unit introdued on either right (2) or left (3) side of thiazolo-erown ether on their potentiometric properties (e.g. ammonium ion selectivity over other cations, response slopes, and detection limits) were not apparent. However, the ammonium ion selectivity of 1,2 and 3 over other alkali metal and alkaline earth metal cations is $10-100$ times higher than that of nonactin.
\end{abstract}

Key Words : Naphtho-crown ethers, Ammonium ion selective. Thiazole. Extraction. Potentiometric

\section{Introduction}

The design and synthesis of highly selective ammonium ionophore has been one of the goals in the development of membrane-based ion selective electrode (ISE) and optodes. due to the important role of the ammonium ion in biological and environmental systems. ' Direct detection of ammonium ion in aqueous systems is essential for the development of ion sensors for application in clinical and environmental analyses. ${ }^{23}$ For potentiometric determination of ammonium ion concentration, nonactin, a natural product, has been widely used as an ion selective membrane electrode since 1970. IJowever, while nonaclin-based membrane electrode show good selcctivity towards the ammonium ion, they nevertheless suffer from other ions, particularly over potassium and sodium ions. To improve the selectivity for ammonium ion over other alkali metal ions, several synthetic ammonium ion scleclive ionophores were designed and synthesized. ${ }^{4-12}$

Recently we reported that thiazolo dibenzo-crown ether TDB18C6 provide enhaned ammonium ion sclectivity over sodium ion (log $\left.K_{x \rightarrow T}^{P O T}--3.9\right)$ and slightly improved over polassium compared io nonactin. ${ }^{4} \mathrm{X}$-ray crystallography, ${ }^{1} \mathrm{~J}$ NMR and theoretical studies suggested that the TDB $18 C 6$ form 2:1 complex with ammonium ion through hydrogen bonding. "Similarly Suzuki showed that decalino-19-crown-6 (TD19C6) exlibited improved selectivity for ammonium

Co-Corresponding Authors. H.-S. Kim (kimhs(akmu.ac.kr); II. Nam (namb(adaisy.kw.ac.kr) over sodium and other alkali metal ions. ${ }^{\text {l" }}$ They proposed that a block-wall effect of the bulky dacalino subunits is responsible for the increased ammonium ion selectivity over potassium and sodium ions by factors of 10 and 3000 times.

As the bulky subunits introduced in the crown ether cavity substantially seem to improve the ammonium ion selectivity over polassium and sodium ions, we examined such structural modification is also applicable to the derivatives of thiazolecontaining crown ethers. We have synthesized thiarolecontaining naphtho-crown elhers and examined their ion selectivity by extraction and potentiometric measurements.

\section{Experimental Section}

Melting points were measured on Thomas Jloover Melting point apparatus and are uncorrected. ${ }^{1} \mathrm{H}$ and ${ }^{19} \mathrm{C}$ NMR spectra were recorded on aVarian Unity Spectrometer ('JI, 300 MII\%: ${ }^{13} \mathrm{C}$ : 75 MII\%) with TMS as an internal standard. IR spectra were measured with a Galaxy FT-IR 7000 spectrophotometer. Mass spectra were recorded on a Shimadzu QP-1000 spectrometer. Elemental analyses were performed at Center for Scientific Instruments, Kyungpook National University. Flash column chromatography was performed with Merck silica gel 60 (70-230 mesh). All reactions were carricd out under an almosphere of argon. The solution was dried over anhydrous sodium sulfate. 2,3Dihydroxynapthalene, iodoacelamide, Lawesson's reagent, 1,3-dichloroacetone, ethyl bromopyruvate, lithium aluminum hydride, carbon tetrabromide, triphenylphosphine, eatechol, and dibenzo-crown ether (DB18C6) were purchased from 
Aldrich. BTB18C6 (1) and BTN18C6 (2) were prepared by literature procedure. ${ }^{4.13}$ Metal, ammonium and amine picrates were prepared by the literature procedure. ${ }^{14}$

Synthesis of 2,3-bis(amidomethyloxy)naplithalene (5). A mixlure of 2,3-diliydroxynaphthalene $(1.00 \mathrm{~g}, 6.24$ mmol), iodoactamide $(2.43 \mathrm{~g}, 13.13 \mathrm{mmol})$, and $\mathrm{K}_{2} \mathrm{CO}_{3}$ (3.45 g, $24.96 \mathrm{mmol}$ ) was refluxed in $100 \mathrm{~mL}$ of acetone for $14 \mathrm{~h}$. Alter the solvent was removed, diluted with water. The solid was collected by filtration and dried in an air to give 5 $(2.99 \mathrm{~g}, 83 \%)$. Mp $236^{\circ} \mathrm{C}\left(\mathrm{CIJ}_{2} \mathrm{Cl} \mathrm{l}_{2}\right.$-hexane); IR (KBr) 3439 , $3377,3227,1682,1479,1250,1031,856,758,602 \mathrm{~cm}^{-1} ;{ }^{1} \mathrm{H}$ NMR (DMSO-d d $\left._{6}\right) \delta 7.71$ (dd, $\left.J-3.3,6.3 \mathrm{~Hz}, 1 \mathrm{H}\right), 7.52$ (bs, $1 \mathrm{IJ}, \mathrm{CON} H), 7.48(\mathrm{bs}, 1 \mathrm{I}, \mathrm{CON} H), 7.32(\mathrm{dd}, J=3.3,6.3 \mathrm{H} \%$ 1H), $7.29(\mathrm{~s}, 1 \mathrm{H}), 4.59\left(\mathrm{~s}, 2 \mathrm{H}, \mathrm{OCH}_{2} \mathrm{CONH}_{2}\right) ; \mathrm{MS} m / 2274$ $\left(\mathrm{M}^{\prime}, 72\right), 172$ (100); Anal. Caled for $\mathrm{C}_{14} \mathrm{H}_{14} \mathrm{~N}_{2} \mathrm{O}_{4}: \mathrm{C}, 61.31$; $\mathrm{H}, 5.14 ; \mathrm{N}, 10.21$. Found; $\mathrm{C}, 60.98 ; \mathrm{H}, 5.20 ; \mathrm{N}, 10.08$.

Synthesis of 2,3-bis(thioamidomethyloxy)naphthalene (6). A mixture of $5(1.00 \mathrm{~g}, 3.65 \mathrm{mmol})$ and Lawesson's reagent $(3.24 \mathrm{~g}, 9.10 \mathrm{mmol})$ was refluxed in THF $(60 \mathrm{~mL})$ for $7 \mathrm{~h}$. After the solvent was removed, treated with dichloromethane $(20 \mathrm{~mL})$, and stirred for $30 \mathrm{~min}$. The solid was filtered and dried to give $6(816 \mathrm{mg}, 73 \%)$. $\mathrm{R}_{f} 0.50$ (E1OAc : hexane 1: 1); $\mathrm{mp} 202$ " $\mathrm{C}\left(\mathrm{CH}_{2} \mathrm{Cl}_{2}\right.$-hexane); $\mathrm{IR}(\mathrm{KBr}) 3360,3260$, $3167,1609,1478,1406,1244,1161,850,650 \mathrm{~cm}^{-1} ;{ }^{1} \mathrm{H}$ N.MR (acetonc- $\left.\mathrm{d}_{6}\right) \delta 9.22(\mathrm{bs}, 1 \mathrm{JI}, \mathrm{CSN} H), 8.91(\mathrm{bs}, 1 \mathrm{JI}$, CSNH), 7.78 (dd, $J-3.3,6.3 \mathrm{~Hz}, 1 \mathrm{H}), 7.42(\mathrm{~s}, 1 \mathrm{H}), 7.38$ $(\mathrm{dd}, J=3.3,6.3 \mathrm{JI} \%, 1 \mathrm{IJ}), 5.01$ (s, 2I I, OC $\left.\mathrm{H}_{2} \mathrm{CSNI} \mathrm{SN}_{2}\right),{ }^{13} \mathrm{C}$ N.MR (acetone- $\left.\mathrm{d}_{6}\right) \delta 206.6\left(\mathrm{CSNH}_{2}\right), 148.7,131.0,127.9$, 126.0, 111.0, 75.5: MS $m / z 302$ (M , 4), 197 (100); Anal. Calcd for $\mathrm{C}_{14} \mathrm{I}_{14} \mathrm{~N}_{2} \mathrm{O}_{2} \mathrm{~S}_{2}: \mathrm{C}, 54.88 ; \mathrm{II}, 4.61 ; \mathrm{N}, 9.14$. Found: C, $54.85 ; \mathrm{H}, 4.46 ; \mathrm{N}, 8.85$.

Synthesis of 2,3-bis[2(4-carbethoxy)thiazolyl]methyloxynaphthalene (7). A mixture of $6(2.46 \mathrm{~g}, 8.13 \mathrm{mmol})$ and elhyl bromopyruvale $(4,00 \mathrm{~g}, 20.50 \mathrm{mmol})$ was relluxed in absolute ethanol $(80 \mathrm{~mL})$ for $5 \mathrm{~h}$ and the solvent was removed. The residue was extracted with dichloromethane, dried, concentrated, and was purified by column chromatography (EtOAc: hexane $1: 2$ ) to give $7(2.96 \mathrm{~g} .73 \%)$. $\mathrm{R}_{\mathrm{f}} 0.30$ (EIOAc: hexane $1: 1)$; mp $168{ }^{\circ} \mathrm{C}$ ( $\mathrm{CII}_{2} \mathrm{Cl}_{2}$-hexane); IR (KBr) 3079, 2982, 1732, 1705, 1485, 1248, 1213, 1097. $1022,852,754 \mathrm{~cm}^{-1}:{ }^{1} \mathrm{JI}$ NMR (CDCl $) \delta 8.23(\mathrm{~s}, 1 \mathrm{II}$, Th\%$H$ ), 7.70 (dd, $J=3.3,6.3 \mathrm{JJ} /, 1 \mathrm{JI}), 7.38$ (dd, $J=3.3,6.3 \mathrm{H} /$, $1 \mathrm{H}), 7.25(\mathrm{~s}, 1 \mathrm{H}), 5.60$ (s, $\left.2 \mathrm{H}, \mathrm{OCH}_{2} \mathrm{Tluz}\right), 4.46$ (q, $J-7.2$ $\mathrm{II} \%, 2 \mathrm{JI}, \quad \mathrm{CO}_{2}\left(\mathrm{CH}_{2} \mathrm{CII}\right), 1.43 \quad(\mathrm{l}, J=7.2 \mathrm{IL} \%, 3 \mathrm{II}$, $\left.\mathrm{CO}_{2} \mathrm{CH}_{2} \mathrm{CH}_{3}\right) ;{ }^{13} \mathrm{C} \mathrm{NMR}\left(\mathrm{CDCl}_{3}\right) \delta 169.5,162.7,148.8$, $130.9,129.5,128.1,126.6,111.2,69.7,63.0,15.8 ;$. MS $m / 2$ $498\left(\mathrm{M}^{-}, 25\right), 171(100)$; Anal. Calcd for $\mathrm{C}_{24} \mathrm{H}_{22} \mathrm{~N}_{2} \mathrm{O}_{6} \mathrm{~S}_{2}: \mathrm{C}$, $57.82 ; \mathrm{H} .4 .45 ; \mathrm{N}, 5.62$. Found: C. $57.97 ; \mathrm{H} .4 .33 ; \mathrm{N}, 5.44$.

Synthesis of 2,3-bis|2(4-bromomethyl)thiazolyl] methyloxynaphthalene (9). To a solution of 7 (348 mg. 0.70 mmol) in dry TIJF $(40 \mathrm{~mL})$ was added $\mathrm{LiAlH}_{4}$ in an ice bath and stirred for $6 \mathrm{~h}$. The solvent was removed, and the residue was treated with $5 \%$ HCl solution, and extracted with ethyl acetale. The organic layer was dried and cvaporated to give crude hydroxymethyl compound $8(258 \mathrm{mg})$. The crude compound was treated with $\mathrm{PPh}_{3}(556 \mathrm{mg}, 2.12 \mathrm{mmol})$ and
$\mathrm{CBr}_{4}(703 \mathrm{mg}, 2.12 \mathrm{mmol})$ in dry dichloromethane $(30 \mathrm{~mL})$ at $5{ }^{\circ} \mathrm{C}$ for $1 \mathrm{~h}$. The resulting mixture was extracted with dichloromethane, dried, and concentrated. The residue was purified by chromatograplyy (EtOAc: hexane $1: 4$ ) to give 9 (310 mg, 82\%). R 0.40 (EtOAc: hexane $1: 2$ ); mp $132{ }^{\circ} \mathrm{C}$ ( $\mathrm{CH}_{2} \mathrm{Cl}_{2}$-hexane); IR (KBr) 3113, 3030, 1514, 1483, 1265 , $1215,1116,856,746 \mathrm{~cm}^{-1}$; 'H NMR (CDCl) 87.70 (dd. $J-$ $3.3,6.3 \mathrm{HE}, 1 \mathrm{II}), 7.37$ (dd, $J=3.3,6.3 \mathrm{HL}, 1 \mathrm{II}), 7.34$ (s. $1 \mathrm{HI}$ ), 7.29 (s, $1 \mathrm{H}, \mathrm{ThzH}), 5.54$ (s, 2H, OCH.Thz), 4.61 (s, $2 \mathrm{H}$, ThyC $\left.\mathrm{H}_{2} \mathrm{Br}\right){ }^{13} \mathrm{C}$ NMR $\left(\mathrm{CDCl}_{3}\right) \delta 167.9,152.0,147.7,129.5$, $126.6,125.0,118.5,110.0,68.3,26.9 ; \mathrm{MS} m / z 542(\mathrm{M}+4,4)$, $540(\mathrm{M}+2,6), 538\left(\mathrm{M}^{+}, 3\right), 111(100)$; Anal. Calcd for $\mathrm{C}_{2 i i} \mathrm{II}_{16} \mathrm{Br}_{2} \mathrm{~N}_{2} \mathrm{O}_{2} \mathrm{~S}_{2}: \mathrm{C}, 44.46:$ II, 2.98; N, 5.18; S, 11.87. Found: $\mathrm{C}, 44.73 ; \mathrm{H}, 3.02 ; \mathrm{N}, 4.94 ; \mathrm{S}, 11.46$.

Synthesis of 2,3-bis[2(4-chloromethyl)thiazolyl|methyloxynaphthalene (10) A mixture of $6(1.00 \mathrm{~g}, 3.26 \mathrm{mmol})$ and 1,3-dichloroacetone (912 $\mathrm{mg}, 7.18 \mathrm{mmol}$ ) in benzene $(70 \mathrm{~mL})$ was refluxed for $20 \mathrm{~h}$ with Dean-Stark column to remove water. After the solvent was removed, extracted with dichloromethane, dried, and concentrated. The residue was purified by column chromatography (EtOAc: hexane $1: 2$ ) to give $10(1.28 \mathrm{~g}, 87 \%) . \mathrm{R}_{\mathrm{t}} 0.58$ (EtoAc: hexane $\left.1: 1\right)$; mp $137^{\circ} \mathrm{C}\left(\mathrm{CH}_{2} \mathrm{Cl}_{2}-\right.$ hexane); IR (KBr) 3110, 3030, 1514, 1448 , 1264, 1117, 851, $744 \mathrm{~cm}^{-1}$; 'H NMR $\left(\mathrm{CDCl}_{3}\right) \delta 7.71-7.68$ (m, 1II), 7.39 (t, 1H), 7.35 (s, 1H, ThrH), 7.29 (s, 1H), 5.54 (s. $\left.2 \mathrm{H}, \mathrm{OCH}_{2} \mathrm{Thz}\right), 4.72$ (s, $2 \mathrm{H}, \mathrm{ThzCH}_{2} \mathrm{Cl}$ ) ${ }^{13} \mathrm{C}$ NMR (CDCl $) \delta 167.9,151.9,147.8,129.5,126.6,125.0,118.4$. 109.9, 68.3, 40.7; MS $m / 2450\left(\mathrm{M}^{+}, 5\right), 146(100)$; Anal.

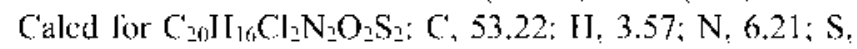
14.21. Found: C, $53.29 ; \mathrm{H}, 3.54 ; \mathrm{N}, 6.00 ; \mathrm{S}, 14.05$.

Synthesis of Naphtho-crown Ethers. After a mixture of catechol $(1.1 \mathrm{eq})$ and $\mathrm{K}_{2} \mathrm{CO}_{3}(2.2 \mathrm{cq})$ was relluxed in acetone $(200 \mathrm{~mL})$ for $\mathrm{l} \mathrm{h}$, compound $9(0.5 \mathrm{eq}$.) was added and conlinued to reflux for $15 \mathrm{~h}$. After the solvent was removed. extracted with dichloromethane, dried, concentrated, and the residue was purified by flash chromatograply (EtOAc: hexane $1 ; 1)$ to give the product.

1,2-Xaphthalene-5,16-dithiazolyl-10,11-benzene coronand $18 \mathrm{C} 6$ (3). This compound was obtained in $92 \%$ yicld as a white solid: $\mathrm{R}_{f} 0.25$ (EtOAc: hexane $1: 1$ ); $\mathrm{mp} 212{ }^{\circ} \mathrm{C}$ (CII $\mathrm{Cl}_{2}$-hexane); IR (KBr) 3101, 3055, 2924, 2864, 1502. $1252,1117,1014,845,741 \mathrm{~cm}^{-1} ;{ }^{1}$ II NMR (DMSO-d $\left.\mathrm{d}_{6}\right) \delta$ $7.74(\mathrm{dd}, J-3.3,6.3 \mathrm{~Hz}, 1 \mathrm{H}), 7.42-7.40(\mathrm{~m}, 1 \mathrm{H}), 7.40(\mathrm{~s}$, 1II), $7.36(\mathrm{~s}, 1 \mathrm{IJ}, \mathrm{Th} \not H), 7.08-6.98(\mathrm{~m}, 2 \mathrm{II}, \mathrm{Ph}), 5.32(\mathrm{~s}, 2 \mathrm{II}$, $\mathrm{NapC} \mathrm{H}_{2} \mathrm{O}$ ), 5.10 (s, $2 \mathrm{H}$, Thz $\mathrm{CH}_{2} \mathrm{O}$ ) ${ }^{13}{ }^{13} \mathrm{C}$ NMR $\left(\mathrm{DMSO}_{-} \mathrm{d}_{6}\right) \delta$ $163.8,152.2,148.7,148.2,129.3,126.1,124.4,121.5$, 118.0, 114.8, 111.1, 67.5, 66.8; $\mathrm{MS} m / 2488\left(\mathrm{M}^{+}, 100\right)$; Anal. Calcd for $\mathrm{C}_{26} \mathrm{H}_{20} \mathrm{~N}_{2} \mathrm{O}_{4} \mathrm{~S}_{2}: \mathrm{C}, 63.92 ; \mathrm{H}, 4.13 ; \mathrm{N}, 5.73$. Found: C. $63.96 ; \mathrm{II}, 4.23 ; \mathrm{N}, 5.47$.

Bis(5,16-thiazolyl-1,2,10,11-naphthalene) coronand $18 \mathrm{C} 6$ (4). This compound was oblained in $70 \%$ yield as a white solid: $\mathrm{R}_{\mathrm{r}} 0.30$ (EtOAc : hexane $\left.\mathrm{I}: \mathrm{l}\right) ; \mathrm{mp} 286{ }^{\circ} \mathrm{C}\left(\mathrm{CH}_{2} \mathrm{Cl}_{2}-\right.$ hexanc); IR (KBr) 3107, 3053, 2926, 2868, 1481, 1251, $1168,995,846,742 \mathrm{~cm}^{-1}$; ${ }^{1} \mathrm{H}$ NMR (DMSO-d 6 ) $\delta 7.95(\mathrm{~s}$, IH, ThzH), $7.78(\mathrm{dd}, J-3.3,6.3 \mathrm{~Hz}, 2 \mathrm{H}), 7.51(\mathrm{~s}, 1 \mathrm{H}), 7.49$ (s, 1H), 7.33-7.39 (m, 2H), 5.38 (s, 2H, NapCH, O), $5.18(\mathrm{~s}$, 
$2 \mathrm{H}$, ThzCH $\mathrm{H}_{2} \mathrm{O}$ ); 'i' $\mathrm{C}$ NMR (DMSO-d $\left.\mathrm{d}_{6}\right) \delta 162.9,152.0$, $148.2,147.8,128.9,126.3,126.2,124.3,124.0,121.6$, $107.6,107.0,64.9 ; \mathrm{MS} m / \mathrm{z} 538(\mathrm{M}, 100)$; Anal. Caled for $\mathrm{C}_{30} \mathrm{II}_{22} \mathrm{~N}_{2} \mathrm{O}_{4} \mathrm{~S}_{2}: \mathrm{C}, 66.89 ; \mathrm{H}_{1} 4.12 ; \mathrm{N}, 5.20$. Found: $\mathrm{C}, 67.19 ;$ $\mathrm{H}, 4.11 ; \mathrm{N}, 5.14$.

Extraction measurements. ${ }^{15,16} \wedge 2.5 \mathrm{~mL}$ of aqueous picrate solution $\left(3 \times 10^{-4} \mathrm{~mol} / \mathrm{L}\right)$ and $2.5 \mathrm{~mL}$ solution of naphtho-crown ethers in 1,2-dichloroethane ( $3 \times 10^{4} \mathrm{~mol} / \mathrm{L}$ ) was magnetically stirred in a stoppered glass tube at $25^{\circ} \mathrm{C}$. The equilibrium was reached after vigorous stirring for $1 \mathrm{~h}$, and kept $12 \mathrm{~h}$ at same temperature. An aliquot of the 1,2dichloroethane $(0.5 \mathrm{~mL})$ was taken with syringe and evaporated to dryness. The residue was diluted with acetonitrile to adjust the UV absorbance within 1.5. The UV absorbance of acetonitrile solution was measured at $376 \mathrm{~nm}$. The extraction percentage was calculated according to the difference between the initial and final concentration of organic phase, and the values are the average of three parallel extraction results.

Preparation of electrodes and their potentiometric evaluation. lon-selective membrancs were prepared with four different ionophores 1-4 by the methods as reported carlier. ${ }^{4.6 .17}$ Membrane cocktails were formulated by dissolving $2 \mathrm{mg}$ ionophore, $66 \mathrm{mg}$ PVC and $132 \mathrm{mg}$ plasticizer (noctylphenyl ether; NPOE) in $1 \mathrm{~mL}$ tetrahydrofuran (THF), poured into glass rings (i.d. $-22 \mathrm{~mm}$ ) mounted on a slide glass, and dried overnight in a dust free chamber at room 1emperature. Membrane disks $(d=5.5 \mathrm{~mm})$ were punched out of the master membranes and mounted in Philips electrode bodies (IS-56I; Glasbläserei Möller, Zürich, Switzerland). The inner filling solution for all electrodes was $0.1 \mathrm{M} \mathrm{NH}_{4} \mathrm{Cl}$. An Orion (Cambridge, MA, USA) sleeve-type double-junction $\mathrm{Ag} / \mathrm{AgCl}$ electrode (Model 90-02) was used as the external reference. The potential differences between the ionselective electrode and the reference clectrode were measured using a $\mathrm{PC}$ equipped with a 16-channel high- impedance input voltmeter (Model KSTI0IB, KOSENTECH, Busan, Korca). Dynamic response curves and calibration plots were obtained by adding calculated amounts of standard solutions 10 a $200 \mathrm{~mL}$ of stirred background electrolyte $(0.05$ $\mathrm{M}$ TRIS-HCl, $\mathrm{pH} \mathrm{7.4)}$ at room temperature; concentrations of primary and interlening ionic species were varied from $10^{\text {th }}$ to $10^{-1} \mathrm{M}$. The response of the electrodes to $\mathrm{pH}$ changes was tested by adding aliquots of $\mathrm{NaOH}$ solution to a buffer composed of $11.4 \mathrm{mM}$ boric acid- $6.7 \mathrm{mM}$ citric acid$10.0 \mathrm{mM} \mathrm{NaH}_{2} \mathrm{PO}$, at room temperature. The solutions were magnetically stirred during all c.m.l. measurements. Selectivity coefficients were determined by using the matched potential method at an interfering ion concentration of 0.1 $\mathrm{M}^{18}{ }^{18}$ Other response characteristics, e.g., detection limits, response slopes, and response times, were determined according to the JUP $\Lambda \mathrm{C}$ recommendation. ${ }^{19}$

\section{Results and Discussion}

We designed and synthesized a new class of ionophore by introducing a rigid naphthalene ring onto the crown ether skeleton. A simple molecular modeling study suggested that the compounds 2,3 and 4 which have rigid naphthalene units in the thiazolo-crown elher structure prefers the $1: 1$ complex with anmonium ion, while the previously known compound 1 form $2: 1$-complex. ${ }^{5}$ It was interesting to see if the change in complex structure would be beneficial for increasing the ammonium ion selectivity over other alkaline metal cations.

For the synthesis of NTB18C6 (3) and NIN18C6 (4), an eflicient and short synthetic scheme for 2,3-bis[2(4halomethyl)thiazolyl]methyloxynaphthalene was rejuired. Previous synthesis of bromomethylthiazole (9) was achieved by three secuential steps from thioamide (6): reaction with ethyl bronopyruvate in dry ethanol to provide the thiazole (7), reduction of 7 with $\mathrm{LiNll}_{4}$ to give 8 and subsequent<smiles>c1ccc2c(c1)OCCOCCOc1ccccc1OCCOCCO2</smiles>

DB18C6<smiles>Cc1ccccc1OCc1csc(COc2ccccc2OCc2nc(COc3ccccc3O)cs2)n1</smiles>

BTB18C6 (1)<smiles>Cc1ccccc1OCc1nc(COc2cc3ccccc3cc2OCc2csc(COc3ccccc3)n2)cs1</smiles>

BTN18C6 (2)<smiles></smiles>

NTB18C6 (3)<smiles></smiles>

NTN18C6 (4)

Figure 1. Structures of ammonium ion-selective neutral carriers. 


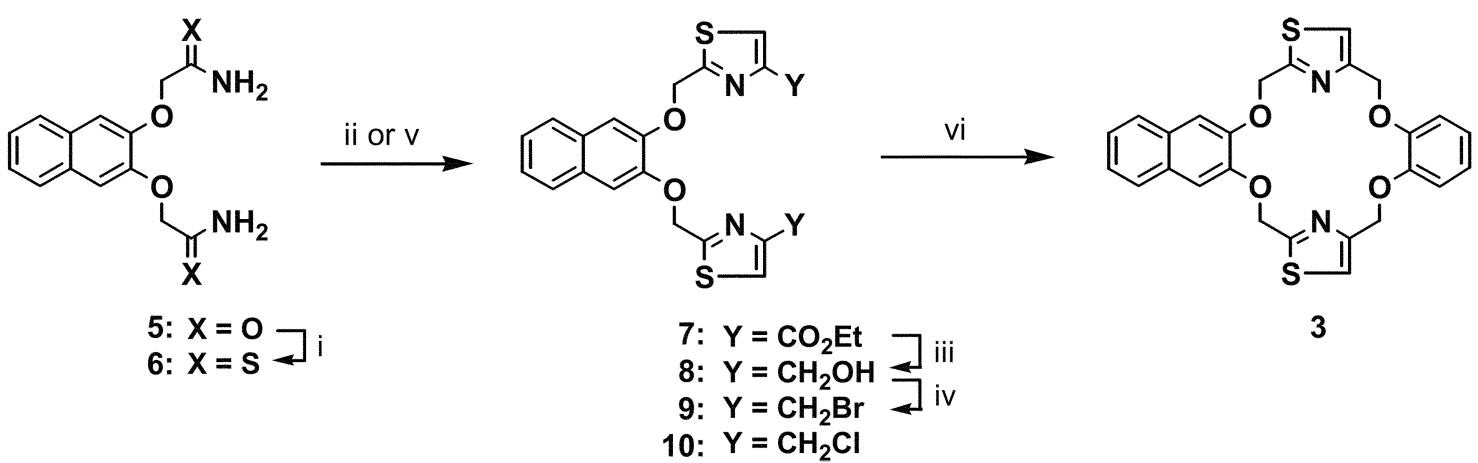

Reaction conditions: i) Lawesson's reagent. THF; ii) $\mathrm{BrCH}, \mathrm{COCO}_{2} \mathrm{Et}, \mathrm{EtOH}$; iii) $\mathrm{LiAlH}_{4}, \mathrm{THF}$; iv) $\left(\mathrm{CBr}_{4}, \mathrm{PPh}_{3}, \mathrm{CH}, \mathrm{Cl}_{2}\right.$; v) 1.3dichloroactone, benzenc; vi) $\mathrm{K}_{2} \mathrm{CO}_{3}$, acetone, catechol.

Scheme 1. Synthetic scheme for naphtho-crown cthers containing thiazole.

bromination with $\mathrm{CBr}_{1}-\mathrm{Pl}_{3}$ to yield 9 in $44 \%$ total yield. For the last construction of halomethylthiazole, reaction of thioamide (6) with 1,3-dichloroacetone was investigated. Reaction of these two reagents in refluxing benzene provided chloromethylthiazole (10) in $87 \%$ yicld. Cyclization of 9 or 10 with catechol or 2,3-dihydroxynapthalene in the presence of $\mathrm{K}_{2} \mathrm{CO}_{3}$ in acetone yiclded 3 and 4 in 92 and $70 \%$ yicld, respectively as shown in Scheme 1 .

The structure of compounds $\mathbf{3}$ and $\mathbf{4}$ were characterized by spectroscopic and elemental analysis. In the 'H NMR spectra of $\mathbf{3}$, thiazole proton appeared at $\delta 7.36$ as singlet, a pair of singlets revealed at $\delta 5.32$ and 5.10 cotresponding to the methylene protons between napthalene and thiazole, and thiazole and benzene moieties, which indicate that this compound has symmetric structure in $\mathrm{CDCl}_{\hat{3}}$. The mass spectrum of 3 also exhibited a peak at $m / 2488$ corresponding to the molecular ion.

In order to investigate the binding ability of these compounds towards different metal ions, and compare recognition selectivity, their extraction behavior towards $\mathrm{Cs}^{\prime}, \mathrm{Rb}^{\prime}, \mathrm{K}^{\prime}, \mathrm{NlI}_{4}, \mathrm{CII}_{3} \mathrm{NI}_{3}{ }^{\prime}$ were carried out. The results of extraction experiments are summarized in Table 1; the selectivity ratio between $\mathrm{NH}_{4}$ and $\mathrm{K}$ follows the trend $3 \approx$ $2>1$. The extractability of compound 4 could not be accurately measured because of its poor solubility in 1,2dichloroethane.

The potassium and ammonium ion extractability of compound 1 was 10 and $21 \%$, respectively, yielding the $\mathrm{NH}_{4}^{-} \mathrm{K}^{+}$extraction selectivity ratio of 2.1 . The naphthalene

Table 1. Extractability of naphtho-crown cthers for cations in picrate extraction

\begin{tabular}{|c|c|c|c|c|c|c|}
\hline & \multicolumn{5}{|c|}{ Fixtractability $(\%)^{a t}$} & Selectivity \\
\hline Ligand & $\mathrm{Cs}^{\circ}$ & $\mathrm{Rb}^{\prime}$ & $\mathrm{K}^{\prime}$ & $\mathrm{NH}_{4}$ & $\mathrm{CH}_{3} \mathrm{NH}_{3}$ & $\mathrm{NH}_{+} / \mathrm{K}^{\prime}$ \\
\hline DBI $8 \mathrm{C} 6$ & 15 & 24 & 19 & 22 & 7 & 1.2 \\
\hline $\mathbf{1}$ & 37 & 31 & 10 & 21 & 19 & 2.1 \\
\hline 2 & 40 & 35 & 15 & 39 & 41 & 2.6 \\
\hline 3 & 38 & 32 & 13 & 36 & 36 & 2.8 \\
\hline
\end{tabular}

"Average and standard deviation for three samples in 1,2-dichlorocthane. unit on the thiazolo-crown ether frame provides enhanced ammonium cxtractability for compounds $2(39 \%)$ and $\mathbf{3}$ $(36 \%)$, which were almost twice compared to that of compound 1, resulting in 1.2-1.3 times increased $\mathrm{NH}_{4}{ }^{1} / \mathrm{K}$ extraction selectivity. It is supposed that the rigid structure of 2 and 3 increases the accessibility of ammonium ion to its nitrogen and oxygen in thiazolo-dibenzocrown ether unit without accompanying the steric hindrance in forming $2: 1$ complex between the ligands and ammonium ion. Molecular modeling of $\mathbf{2}$ and 3, which have naphthalene unit on the right and left side of thiazole structure, respectively, converge to similar structures in the presence of ammonium ion, forming hydrogen bonds between ammonium ion and nitrogens in facially aligned thiazole rings (saddle-like structure). However, their cquilibrium structures in the absence of ammonium ion are quite different; the two five membered thiazole rings in $\mathbf{3}$ are at opposite position with respect to nitrogen, while in $\mathbf{2}$ the same facial position. It means that the compound 3 may require additional energy for conformational change to form a complex with ammonium ion. Ilowever, the extraction experimental results indicate that such conformational change affect little on the ammonium ion binding ability of compound 3 .

To see if the enhanced ammonium ion extractability and selectivity in solution phase also reflected in their potentiometric selectivily of the compounds $\mathbf{1 - 4}$ doped in organic polymer phase, we prepared ammonium ion-selective ISEs with NPOE-plasticized PVC membranes. Potentiometric responses of the membranes to alkali metal and alkaline earth metal cations and to ammonium ion were measured. Figure 2 shows the responses of electrodes, and Table 2 summarizes the results: electrodes based on compounds 1,2 , and 3 exhibit Nemstian response to ammonium with detection limits below $10^{-5}$.

It was observed that the ammonium ion selectivity of 1,2 and 3 over other alkali metal and alkaline earth metal cations is 10-100 times higher than that of nonactin. It was possible to prepare the same PVC/NPOE-based membranes with compound $\mathbf{4}$ as it was dissolved well in THF. However, the very rigid structure of compound $\mathbf{4}$ greatly reduced the 

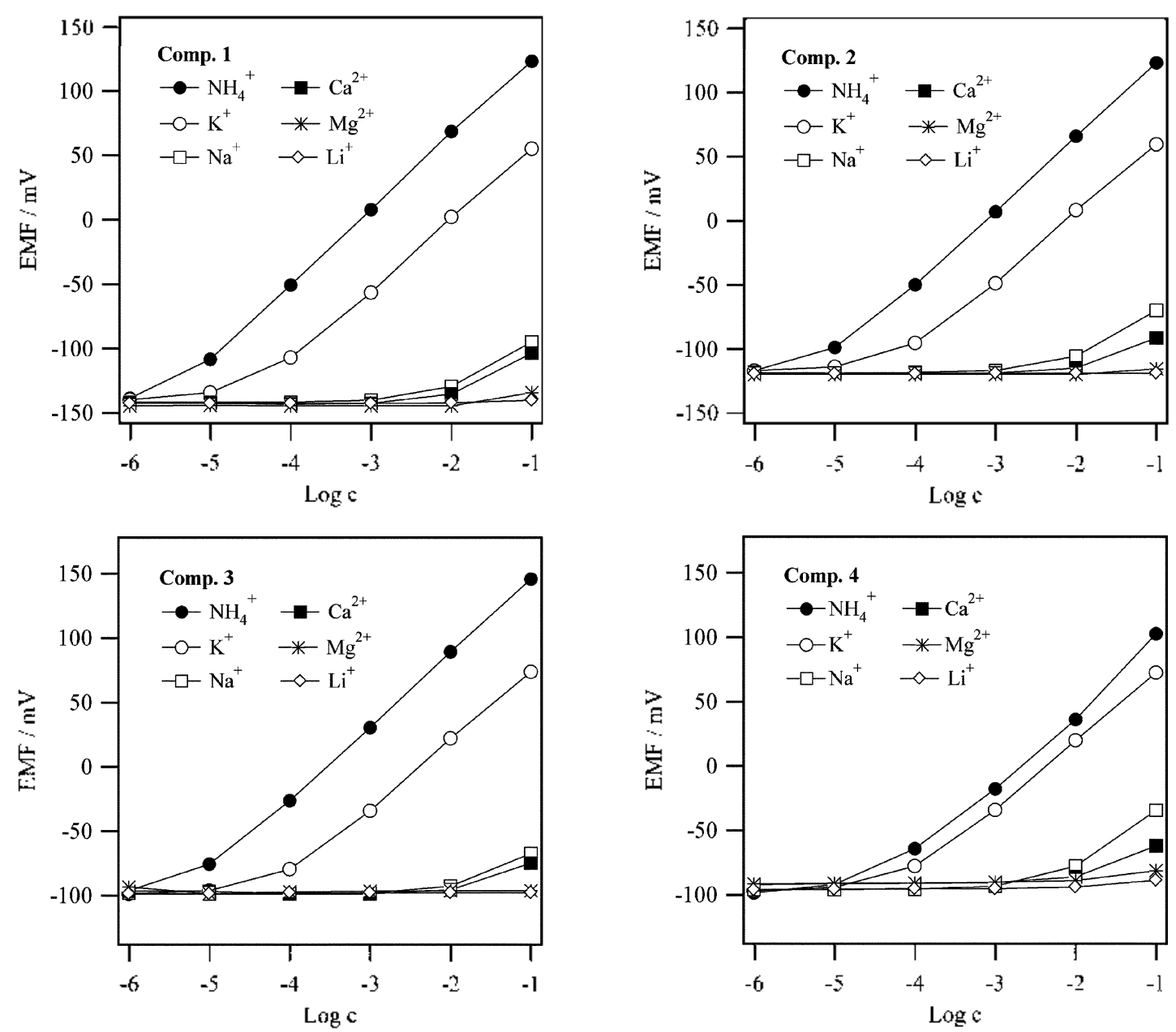

Figure 2. Potentiometric responses of the NPOE-plasticized PVC membranes prepared with naphtho-crown ethers containing thiazole.

Table 2. Potentiometric properties of ammonium ion-selective neutral carriers in. NPOE-plasticized PVC membranes

\begin{tabular}{|c|c|c|c|c|c|c|c|}
\hline \multirow{2}{*}{ Compound } & \multirow{2}{*}{ slope } & \multirow{2}{*}{ detection limit ${ }^{h}$} & \multicolumn{5}{|c|}{ selectivity coefficient ( $\left.\log k_{W H I_{1, j}}^{m o I}\right)$} \\
\hline & & & $\mathrm{Mg}^{2}$ & $\mathrm{Li}$ & $\mathrm{Na}$ & $\mathrm{K}^{-}$ & $\mathrm{Ca}^{2}$ \\
\hline 1 & 58.7 & -5.6 & -4.9 & -5.4 & -3.8 & -1.2 & -3.9 \\
\hline 2 & 57.8 & -5.2 & -4.9 & -5.8 & -3.4 & -1.1 & -3.8 \\
\hline 3 & 57.6 & -5.3 & -4.0 & -6.0 & -3.8 & -1.3 & -4.9 \\
\hline 4 & 55.5 & -4.6 & -3.6 & -3.9 & -2.4 & -0.5 & -3.0 \\
\hline
\end{tabular}

"Slopes from $10^{-5}$ to $10^{-1} \mathrm{M}$ (mVidecade). "I.og $\left[\mathrm{NH}_{-}^{-}\right]$

ammonium selectivity over potassium and sodium, indicating the loss of optimal conformation for hydrogen bonding formation with ammonium. Another plausible reason for reduced potentiometric performance is attributable to the reduced solubility of compound 4 in organic solvent; the elfective concentration of compound 4 in solvent polymeric membrane may have not execeded the critical concentration needed to exhibit theoretical behavior. Although we were not able to obtain new naphthothiazole-based ionophores that exhibit far enhanced ammonium selectivity compared to the ones reported in our previous work, the naphthalene unit containing compounds 2,3 and 4 provided valuable insights into the future design of ammoniun-selective ionophores.
We are now examining the effect of various electron withdrawing or donating groups about the naphthothiazolo crown ether structures on the ammonium ion selectivity, and will be published elsewhere.

Acknowledgement. This work was supporled by Korca Sanhak Foundation (20000397), Insung Chromatech, and BK 21.

\section{References}

1. Bühlmnan, P; Pretch, E.: Bakker, E. Chem. Rev 1998, 98, 1593.

2. Dobler. M. In Compnehensive Supramolecular Chemistry; Alwood, 
I. L.; Davies, J. E. D.; MacNicol, D. D.; Vögtle, F., Edds; Pergamon: Oxford, 1996; Vol. 1.

3. JJa], E. A. JJ. Biosensors; Open University Press: Buckingham, U.K., 1990: chapler 9.

4. Kim, H.-S.; l’ark, H. J.; Oh, H. J.; Koh, Y. K.; Choi, J.-H.; Lee. D.H.; Cha, G. S.; Nam. H. Anal. Chem. 2000. 7?, 4683.

5. Kariuki, B. M.; Lee, S.-O.; I Jarris, K. D. M.; Kim, H.-S.; Do, K.S.; Kim, K.-I. Cnst. Growth \& Desigh 2002, 2, 309.

6. Kim, IJ.-S.; Kim, D. I1.; Kim, K. S.; Choi, H. J.; Shim, J. II.; Jeong, I. S.; Cha, G. S.; Nam, H. J. Inchusion Phenom. Macoycyclic Chom, 2003, 46, 201.

7. Jin, H. Y.; Kim, I. H.; Kim, J.; Lee, S. S.; Kim, J. S. Bull Komem Chem. Soc. 2004, 25,59.

8. (a) Campayo, L.; Pardo, M.; Cotillas, A.; Jaúregui, O.; Yunta, M. J. R.; Cano, C.; Gomez-Contreas, F; Navamo. P.; Sanz, $\Lambda$. M. letrahedron 2004, 60, 979. (b) Navanto, l': Rodriguez-Hánico, M. l.; Foces-Foces, C.; Cano, F, Samal, A. J. Or w. Chem. 1989, 54. 1391.

9. Benco, J. S.; Nienaber, II. A.; Merimpsey, W. G. Ahal. Chem. $2003,75,152$

10. (a) Sasaki. S.; Amano, T.; Monma, G.: Otsuka, T.: Iwasawa, N.; Cillerio, D:; Hisamolo, H.; Suzuki. K. Anal Chem. 2002, 74. 4845. (b) Suzukj, K.: Siswanta, D.: Olsuka, T:; Amano, T,; Ikeda, I.; Hisamoto, H.: Yoshibara, R; Olibal. S. Anal. Chem. 2000, 72. 2200 .
11. (a) Chin, J.; Oh, J.; Jon, S. Y.; Park, S. II.; Walsdorff; C.; Stranix, B.: Ghoussoub, A.: Lee, S. J.; Chung, II. J.; Park, S.-M.; Kim, K.J. Am. Chem. Soc 2002, I24, 5374. (b) Ahn, K. II.; Kim, S.-G.; Jung. J.; Kim, K.-H.; Chin, J.; Kim, K. Chem. Leff, 2000 , 170. (c) Chin. J.; Oh. J.; Walsdorf, C; Stranix, B; Oh, J.; Chung, H. J.; Park. S.-M.; Kim. K. Angeru: Chem. Int Ed. 1999. 38,2756 .

12. Graf, L.; Kintzinger, J. P.; Lehn, I. M.; LeMoigne, I. .J Am. Chem. Soc. 1982, 104. 1672

13. (a) Kim, H.-S.; Koh, Y. K.; Choi. J. H. J. Hetrockdic Chem. 1998. 35, 177, (b) Choi. J.-H.; Koh, Y, K.; Kwon, 1.-C.; Kim, H.-S.; Park, H. J.; Kim, S. J.; Cha, G. S.; Nam, H. Bull. Korean Chem. Soc. 1999, 20, 581 .

14. Ouchi, M.; Inoue, Y.; Sakamoto, II.; Yamahira. A.; Yoshinaga, M.: Hakushi, T. J. Org. Chem. 1983, 48,3l68.

15. Nolte, R. J, M.; Cram, D. J. J. Am. Chem. Soc, 1984, 106, 1416.

16. Ouchi, M.; Inoue, Y.; Wada, K.; Iketani, S.-1.; Hakushi. T.; Weber. E. J. Org. Chem. 1987. 52, 2420.

17. Oh, II. I.; Cha, G. S.; Nam, II. Bull. Korean Chem. Soc. 2003, 24, 37.

18. Gadzckpo, V. P. Y.; Christian, G. D. Anal Chim. Acta 1984. I64, 279.

19. (a) Buck. R. P; Lindner. E. Pure Appl. Chem. 1994, 66. 2527, (b) Unezawa, Y.; Unezawa, K.; Sato, H. Pure Appl. Chem. 1995. 67. 507. 